\title{
Evaluation of a ribosomal RNA gene probe for the identification of species and subspecies within the genus Staphylococcus
}

\author{
Marie-Laure De Buyser, $\dagger$ Anne Morvan, Sylvie Aubert, Françoise Dilasser $\dagger$ and \\ NÉVINE EL SOLH*
}

Centre National de Référence pour les Staphylocoques, Laboratoire des Staphylocoques et des Streptocoques, Institut Pasteur, 75724 Paris Cedex 15, France

(Received 18 September 1991; revised 3 January 1992; accepted 29 January 1992)

\begin{abstract}
To evaluate a 16S rRNA gene probe for the identification of staphylococcal species and subspecies, we have augmented previous studies involving 12 staphylococcal species by analysing the remaining 16 species currently classified in the genus Staphylococcus. HindIII- and EcoRI-restricted DNA of isolates from validly described species of Staphylococcus was probed with radiolabelled plasmid pBA2 containing 16S rDNA from Bacillus subtilis. The Dice coefficient was used to assess similarity between the 74 HindIII- and the 81 EcoRI-hybridization patterns obtained from a total of 271 isolates belonging to 31 staphylococcal taxa (28 species, of which three include two subspecies). The use of HindIII yielded a better discrimination of the staphylococci than the use of $E c o R I$. All of the isolates belonging to the same species or subspecies, except $S$. hyicus isolates, were recovered as homogeneous clusters using their HindIII hybridization patterns. The phenotypically close taxa were clearly distinguished. Thus, the method presented in this study constitutes a powerful tool for the identification of taxa within the genus Staphylococcus.
\end{abstract}

\section{Introduction}

In the 8th edition of Bergey's Manual of Determinative Bacteriology, the genus Staphylococcus consisted of three species (Baird-Parker, 1974). Currently, 28 species of Staphylococcus and ten subspecies are recognized on the basis of DNA-DNA hybridization (De la Fuente et al., 1985; Kloos \& Schleifer, 1986; Igimi et al., 1989, 1990; Bannerman \& Kloos, 1991; Kloos \& Wolfshohl, 1991). Simplified identification schemes are regularly modified in order to discriminate between these taxa. However, because of the limited number of stable discriminating characteristics, many of the taxa remain difficult to distinguish from one another by phenotypic tests (Devriese et al., 1985; Kloos \& Schleifer, 1986; Hébert et al., 1988; Igimi et al., 1989; Brun et al., 1990; Kloos \& George, 1991). Several other approaches have been proposed in order to differentiate between staphylococcal species. The methods include: numerical taxonomy (Goodfellow et al., 1983; Gunn et al., 1983; Hoover et al.,

\footnotetext{
* Author for correspondence. Tel. 145688363 ; fax 143069835.

† Present address: Centre National d'Études Vétérinaires et Alimentaires, Laboratoire Central d'Hygiène Alimentaire, 43 rue de Dantzig, 75015 Paris, France.
}

Abbreviation: HP, hybridization patterns.
1983); cell wall peptidoglycan and teichoic acid composition (Endl et al., 1983; Schumacher-Perdreau et al., 1983); bacteriolytic activity patterns (Varaldo \& Satta, 1978); serotyping (Pillet \& Orta, 1981); electrophoretic comparison of isofunctional enzymes (Götz \& Schleifer, 1976; Zimmerman \& Kloos, 1976; Zimmerman, 1976); immunological relatedness of catalases (Schleifer et al., 1979) and fructose-1,6-diphosphate aldolases (Fischer $e t$ al., 1983); gel electrophoresis of cellular proteins (Clink \& Pennington, 1987; Pennington et al., 1991) and penicillin-binding proteins (Fontana et al., 1981; Pierre et al., 1990); fatty acid profiles (O'Donnell et al., 1985); Fourier-transform infrared spectroscopy patterns (Helm et al., 1991); and endonuclease-cleaved cellular. DNA (Bialkowska-Hobrzanska et al., 1990a) and rRNA gene polymorphisms (De Buyser et al., 1989; Thomson-Carter et al., 1989; El Solh et al., 1990; Bialkowska-Hobrzanska et al., 1990b; Pennington et al., 1991). Since these methods have been used on only a limited number of staphylococcal species, their ability to discriminate between all species is uncertain. The method used in the current study is based on rRNA gene polymorphisms (De Buyser et al., 1989) using pBA2 (Iglesias et al., 1983) containing 16S rDNA of Bacillus subtilis as a probe and $H$ HindII and EcoRI to cleave the cellular DNA from a 
comprehensive range of staphylococci. We have thus augmented two previous studies involving 14 staphylococcal taxa including 12 species and five subspecies (De Buyser et al., 1989; El Solh et al., 1990) by analysing the remaining 17 taxa including 16 species and one subspecies.

\section{Methods}

Bacterial isolates. The 75 epidemiologically unrelated isolates studied came from human (16 isolates), animal ( 30 isolates), food derived from animals ( 26 isolates) and unknown ( 3 isolates) sources (Table 1). These isolates represent 17 staphylococcal taxa including 16 species and one subspecies. The isolates chosen were those which could be assigned to

Table 1. Characteristics of the 75 staphylococcal isolates

\begin{tabular}{|c|c|c|c|c|}
\hline $\begin{array}{c}\text { Taxon and strain } \\
\text { designation }\end{array}$ & Source* & $\begin{array}{l}\text { Isolated } \\
\text { from: }\end{array}$ & $\begin{array}{c}\text { HindIII } \\
\text { hybridization } \\
\text { pattern }\end{array}$ & $\begin{array}{c}E c o R I \\
\text { hybridization } \\
\text { pattern }\end{array}$ \\
\hline $\begin{array}{l}\text { S. aureus } \\
\text { subsp. anaerobius } \\
\text { ATCC 35844† } \\
\text { MVF } 25 \\
\text { MVF } 39 \\
\text { MVF 41 } \\
\text { MVF 43 }\end{array}$ & K. H. Schleifer & Sheep & $\begin{array}{l}\text { H99 } \\
\text { H99 } \\
\text { H99 } \\
\text { H99 } \\
\text { H99 }\end{array}$ & $\begin{array}{l}\text { E99 } \\
\text { E99 } \\
\text { E99 } \\
\text { E99 } \\
\text { E99 }\end{array}$ \\
\hline $\begin{array}{l}\text { S. delphini } \\
\text { ATCC 49171† } \\
\text { ATCC } 49172\end{array}$ & P. E. Varaldo & Dolphin & $\begin{array}{l}\mathrm{H} 900 \\
\mathrm{H} 900\end{array}$ & $\begin{array}{l}\text { E900 } \\
\text { E900 }\end{array}$ \\
\hline $\begin{array}{l}\text { S. schleiferi } \\
\text { ATCC 43808† } \\
88193 \\
88271 \\
82558\end{array}$ & $\left\{\begin{array}{l}\text { J. Freney } \\
\text { FNRCS }\end{array}\right.$ & $\begin{array}{l}\text { Man } \\
\text { Unknown }\end{array}$ & $\begin{array}{l}\text { H120 } \\
\text { H121 } \\
\text { H121 } \\
\text { H121 }\end{array}$ & $\begin{array}{l}\text { E120 } \\
\text { E121 } \\
\text { E121 } \\
\text { E121 }\end{array}$ \\
\hline $\begin{array}{l}\text { S. capitis } \\
\text { ATCC } 27840 \dagger \\
\text { HM 11 } \\
75768 \\
78008 \\
86163\end{array}$ & $\left\{\begin{array}{l}\text { W. E. Kloos } \\
\text { FNRCS }\end{array}\right.$ & Man & $\begin{array}{l}\text { H130 } \\
\text { H130 } \\
\text { H130 } \\
\text { H130 } \\
\text { H131 }\end{array}$ & $\begin{array}{l}\text { E130 } \\
\text { E130 } \\
\text { E130 } \\
\text { E130 } \\
\text { E131 }\end{array}$ \\
\hline $\begin{array}{l}\text { S. auricularis } \\
\text { ATCC 33753† } \\
\text { ATCC } 33750 \\
\text { BB 1 } \\
\text { CH } 44\end{array}$ & $\begin{array}{l}\text { W. E. Kloos } \\
\text { M. L. De Buyser }\end{array}$ & $\begin{array}{l}\text { Man } \\
\text { Goat's milk }\end{array}$ & $\begin{array}{l}\text { H140 } \\
\text { H140 } \\
\text { H140 } \\
\text { H141 }\end{array}$ & $\begin{array}{l}\text { E140 } \\
\text { E140 } \\
\text { E140 } \\
\text { E141 }\end{array}$ \\
\hline $\begin{array}{l}\text { S. simulans } \\
\text { ATCC 27848† } \\
78078 \\
77398 \\
\text { MAW } 222\end{array}$ & $\begin{array}{l}\text { W. E. Kloos } \\
\text { FNRCS } \\
\text { W. E. Kloos }\end{array}$ & Man & $\begin{array}{l}\text { H100 } \\
\text { H100 } \\
\text { H100 } \\
\text { H100 }\end{array}$ & $\begin{array}{l}\text { E100 } \\
\text { E100 } \\
\text { E101 } \\
\text { E102 }\end{array}$ \\
\hline $\begin{array}{ll}\text { CH } & 38 \\
\text { CH } & 137 \\
\text { CH } & 235 \\
\text { CH } & 173 \\
\text { CH } & 154\end{array}$ & M. L. De Buyser & Goat's milk & $\begin{array}{l}\text { H101 } \\
\text { H101 } \\
\text { H102 } \\
\text { H102 } \\
\text { H102 }\end{array}$ & $\begin{array}{l}\text { E103 } \\
\text { E104 } \\
\text { E105 } \\
\text { E105 } \\
\text { E105 }\end{array}$ \\
\hline $\begin{array}{l}\text { S. felis } \\
\text { ATCC } 49168 \dagger \\
\text { GD } 104\end{array}$ & S. Igimi & Cat & $\begin{array}{l}\text { H920 } \\
\text { H921 }\end{array}$ & $\begin{array}{l}\text { E920 } \\
\text { E921 }\end{array}$ \\
\hline $\begin{array}{l}\text { S. carnosus } \\
\text { DSM 20501† } \\
\text { TM } 300 \\
\text { PCA 43 } \\
\text { PCT 20 }\end{array}$ & $\left\{\begin{array}{l}\text { DSM } \\
\text { F. Götz }\end{array}\right.$ & \} Meat & $\begin{array}{l}\text { H110 } \\
\text { H110 } \\
\text { H110 } \\
\text { H110 }\end{array}$ & $\begin{array}{l}\text { E110 } \\
\text { E110 } \\
\text { E110 } \\
\text { E110 }\end{array}$ \\
\hline $\begin{array}{l}\text { S. caprae } \\
\text { CCM 3573† } \\
141-15 \\
\text { CH } 55 \\
\text { CH } 150 \\
\text { CH } 244 \\
\text { CH } 116 \\
\text { CH } 121\end{array}$ & $\{$ L. A. Devriese & Goat's milk & $\begin{array}{l}\text { H800 } \\
\text { H800 } \\
\text { H800 } \\
\text { H800 } \\
\text { H800 } \\
\text { H800 } \\
\text { H800 }\end{array}$ & $\begin{array}{l}\text { E800 } \\
\text { E801 } \\
\text { E801 } \\
\text { E801 } \\
\text { E801 } \\
\text { E801 }\end{array}$ \\
\hline
\end{tabular}


Table 1.-(continued).

\begin{tabular}{|c|c|c|c|c|}
\hline $\begin{array}{l}\text { Taxon and strain } \\
\text { designation }\end{array}$ & Source* & $\begin{array}{l}\text { Isolated } \\
\text { from: }\end{array}$ & $\begin{array}{c}\text { HindIII } \\
\text { hybridization } \\
\text { pattern }\end{array}$ & $\begin{array}{c}\text { EcoRI } \\
\text { hybridization } \\
\text { pattern }\end{array}$ \\
\hline \multicolumn{5}{|l|}{ S. caseolyticus } \\
\hline ATCC 13548† & CIP & Milk & H190 & E190 \\
\hline CH 18 & M. L. De Buyser & Goat's milk & H190 & E191 \\
\hline \multicolumn{5}{|l|}{ S. saccharolyticus } \\
\hline DSM 20359† & CIP & Unknown & H195 & E195 \\
\hline \multicolumn{5}{|l|}{ S. equorum } \\
\hline DSM 20674† & \multirow{4}{*}{ L. A. Devriese } & \multirow{4}{*}{ Horse } & H38 & E35 \\
\hline PA 209 & & & H38 & E35 \\
\hline PA 219 & & & H38 & E35 \\
\hline PA 235 & & & H38 & E35 \\
\hline CH 65 & M. L. De Buyser & Goat's milk & H38 & E35 \\
\hline 78037 & FNRCS & Horse & H38 & E34 \\
\hline $\mathrm{CH} 100$ & M. L. De Buyser & Goat's milk & H39 & E36 \\
\hline \multicolumn{5}{|l|}{ S. sciuri } \\
\hline ATCC $29062 \dagger$ & \multirow{4}{*}{ W. E. Kloos } & \multirow{5}{*}{$\begin{array}{l}\text { Squirrel } \\
\text { Unknown } \\
\text { Opossum } \\
\text { Man } \\
\text { Goat's milk }\end{array}$} & H810 & E810 \\
\hline ATCC 29068 & & & H810 & E810 \\
\hline ATCC 29059 & & & H810 & E810 \\
\hline ATCC 29060 & & & H811 & E811 \\
\hline CH 231 & M. L. De Buyser & & H812 & E812 \\
\hline \multicolumn{4}{|l|}{$S$. lentus } & - \\
\hline ATCC $29070 \dagger$ & \multirow{3}{*}{ W. E. Kloos } & \multirow{3}{*}{ Goat } & H820 & E820 \\
\hline K 12 & & & H820 & E820 \\
\hline K 15 & & & H820 & E820 \\
\hline CH 174 & \multirow{4}{*}{ M. L. De Buyser } & \multirow{4}{*}{ Goat's milk } & H820 & E820 \\
\hline CH 95 & & & H820 & E820 \\
\hline CH 224 & & & H820 & E820 \\
\hline CH 250 & & & H820 & E821 \\
\hline \multicolumn{5}{|l|}{ S. gallinarum } \\
\hline CCM $3372 \dagger$ & \multirow{3}{*}{ L. A. Devriese } & \multirow{3}{*}{ Poultry } & H150 & $\mathrm{E} 150$ \\
\hline P 21 & & & H151 & E151 \\
\hline P 57 & & & H151 & E152 \\
\hline \multicolumn{5}{|l|}{$S$. arlettae } \\
\hline DSM 20672† & \multirow{4}{*}{ L. A. Devriese } & \multirow{4}{*}{ Poultry } & $\mathrm{H} 160$ & E160 \\
\hline DSM 20673 & & & H160 & E160 \\
\hline BP 32 & & & H160 & E160 \\
\hline BP 36 & & & H160 & E160 \\
\hline \multicolumn{5}{|l|}{ S. kloosii } \\
\hline DSM 20676† & \multirow{4}{*}{ L. A. Devriese } & \multirow{4}{*}{ Animal } & H170 & E170 \\
\hline DM 93 & & & H171 & E171 \\
\hline $\begin{array}{l}\text { SC } 220 \\
\text { PI 427 }\end{array}$ & & & H172 & E172 \\
\hline PI 427 & & & H173 & E173 \\
\hline
\end{tabular}

* K. H. Schleifer, Microbiologie Technische Universität, Munich, Germany; P. E. Varaldo, School of Medicine, University of Ancona, Ancona, Italy; J. Freney, Faculté de Médecine Alexis Carrel, Lyon, France; W. E. Kloos, North Carolina State University, Raleigh, North Carolina, USA; M. L. De Buyser, Laboratoire Central d'Hygiène Alimentaire, Paris, France; S. Igimi, National Institute of Health, Tokyo, Japan; F. Götz, Microbiologie Technische Universität, Munich, Germany; L. A. Devriese, Faculty of Veterinary Medicine, Gent, Belgium; FNRCS, French National Reference Centre for Staphylococci, Institut Pasteur, Paris, France; DSM, Deutsche Sammlung von Mikroorganismen, Göttingen, Germany; CIP, Collection de Bactéries de l'Institut Pasteur, Paris, France.

$\dagger$ Type strain.

known staphylococcal taxa according to published identification schemes (Devriese et al., 1985; De la Fuente et al., 1985; Kloos \& Schleifer, 1986; Freney et al., 1988; Varaldo et al., 1988; Igimi et al., 1989). The biochemical tests used were those previously described (De Buyser et al., 1989).

Isolation and labelling of plasmid DNA. Plasmids pBR322 (Bolivar $e t$ al., 1977) and pBA2 (Iglesias et al., 1983) were used as probes in the hybridization experiments. Plasmid pBA2 contains a $2.3 \mathrm{~kb}$ Bacillus subtilis DNA fragment encoding $16 \mathrm{~S}$ rRNA inserted in the HindIII site of pBR322. Plasmids were isolated, purified and labelled with $[\alpha-$ ${ }^{32}$ P)dCTP (110 TBq $\mathrm{mmol}^{-1}$ ) as previously described (De Buyser et al., 1989).

Gel electrophoresis of endonuclease-cleaved DNA, Southern transfer and hybridization. Extraction of cellular DNA from staphylococcal isolates, 


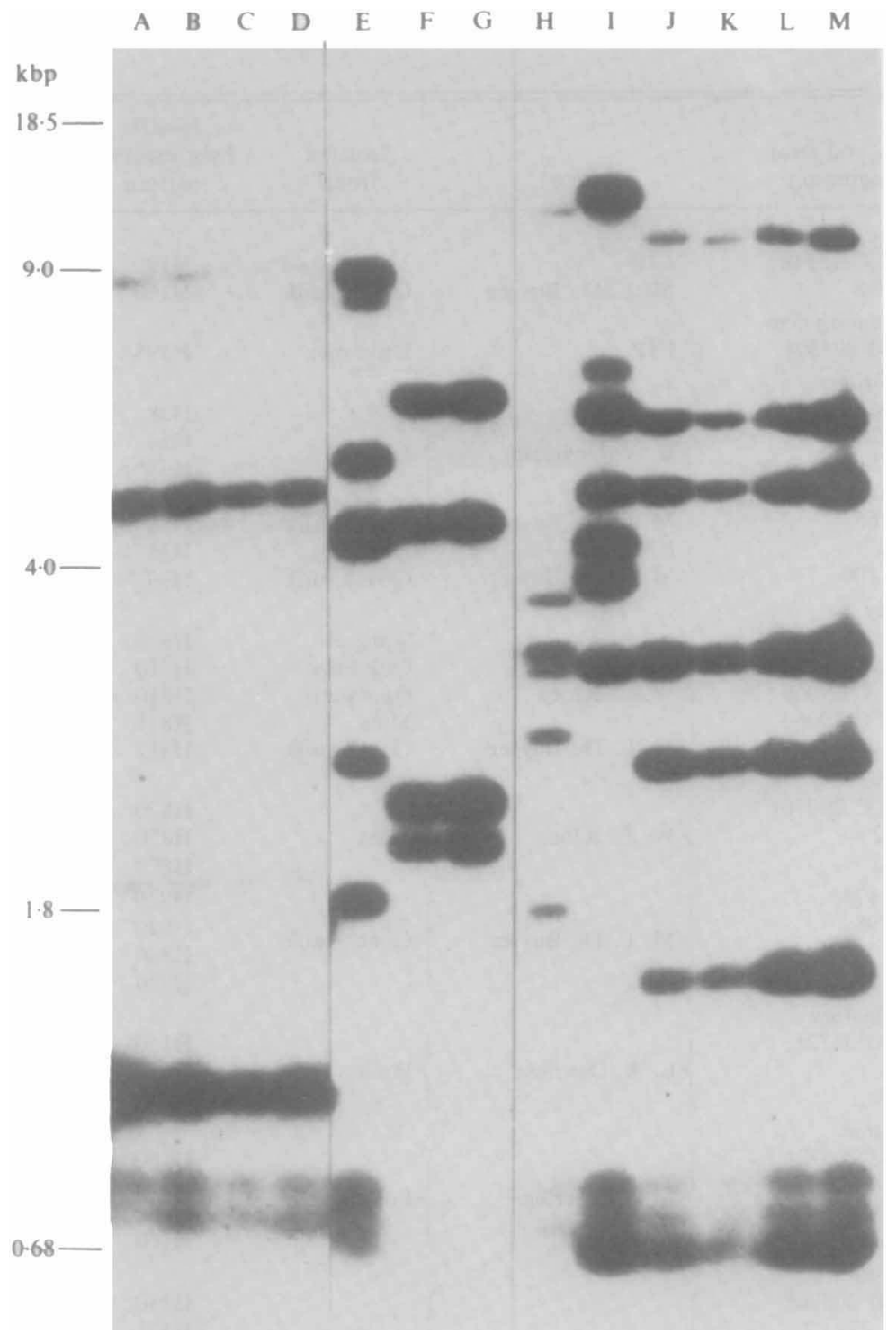

Fig. 1. Autoradiogram of HindIII-digested cellular DNA from 13 staphylococcal strains, separated by electrophoresis and probed with $\alpha_{-32}$ P-labelled plasmid pBA2. Lanes A to D, $S$. aureus subsp. anaerobius strains ATCC 35844†, MVF 25, MVF 39, MVF 41; lane E, $S$. caprae strain CCM $3573 \dagger$; lanes F to G, S. caseolyticus strains ATCC 13548†, CH 18; lane H, S. saccharolyticus strain DSM 20359†; lane I, S. simulans strain CH 235; lanes J to M, S. carnosus strains DSM 20501†, TM 300, PCA 43, PCT 20. $\dagger$ Type strain.

cleavage with restriction endonucleases HindIII or EcoRI, separation by electrophoresis, blotting on nylon membranes of DNA restriction fragments and hybridization with the probes were carried out as previously described (De Buyser et al., 1989). The molecular size marker used was a Raoul I ladder (Appligène, France).

Comparison of hybridization patterns $(H P)$. The sizes of the bands appearing in the HP of the isolates included in this study and of those described in our previous studies (De Buyser et al., 1989; El Solh et al., 1990) were entered on a IBM/PS2 computer. The similarity between any two HP was evaluated according to the Dice coefficient (Dice, 1945).

Clustering of HP was based on the centroid linkage algorithm [BMDP 2M statistical program (1990), University of California Press, Berkeley, USA]. This program joins HP and/or clusters of HP in a stepwise manner until all cases are combined into one cluster. The algorithm uses the distance between the centres of each cluster as a criterion for joining (amalgamating) clusters.

\section{Results}

Each of the HindIII- or EcoRI-cleaved staphylococcal cellular DNAs was probed with pBR322. No restriction fragments hybridized with pBR322; hence, pBA2 was used as a probe for the visualization of rRNA genes without separating the $16 \mathrm{~S}$ rDNA insert from the pBR322 vector.

Using pBA2 as a probe, the 75 staphylococcal isolates belonging to 17 staphylococcal taxa (16 species and one subspecies) (Table 1) yielded 30 distinct HindIII HP and 38 distinct $E c o$ RI HP. Fig . 1 shows the HindIII HP of 13 isolates belonging to six distinct taxa. HP are schematically represented in Figs 2 and 3. Different patterns were 


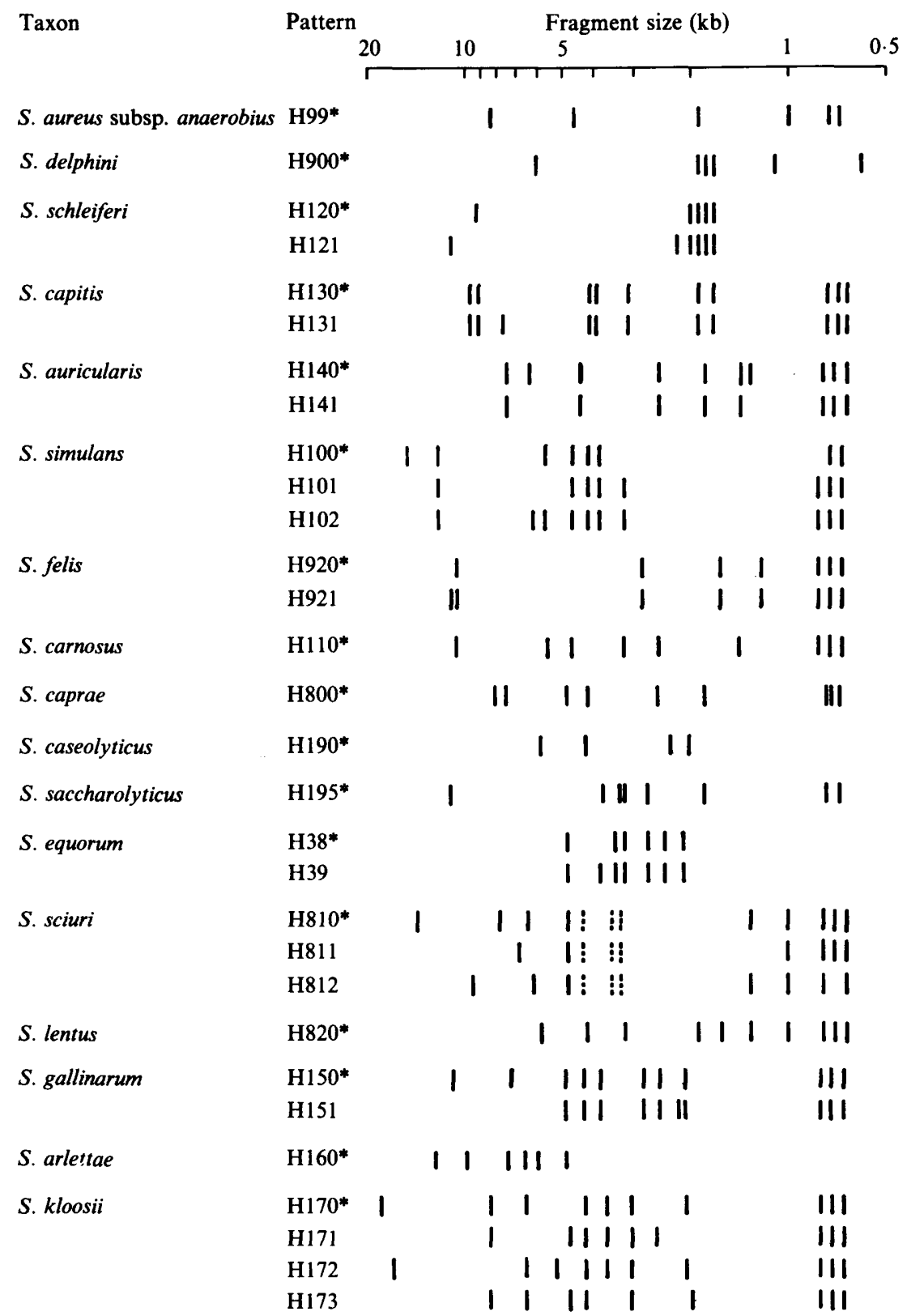

Fig. 2. Schematic representation of the 30 HindIII-HP detected among the 75 staphylococcal isolates studied. Dashed lines indicate very weakly labelled bands. The patterns marked with an asterisk $\left(^{*}\right)$ are those corresponding to the type strain of each taxon.

observed for the isolates belonging to distinct taxa (species and subspecies). One to four HindIII HP and one to six EcoRI HP were detected within each taxon.

The 74 HindIII HP and 81 EcoRI HP obtained from 271 isolates belonging to 28 species and six subspecies $(31$ taxa in all), including the 75 isolates described in this study (Table 1) and the 196 previously described independent isolates (De Buyser et al., 1989; El Solh et al., 1990) were compared.

Each of the 31 staphylococcal taxa analysed was characterized by a core of common bands hybridizing with pBA2. For each taxon, the number of common bands varied with the restriction enzyme used. With EcoRI-digested DNA, the taxon-specific core consisted of three bands for $S$. aureus, and five to ten bands for each of the remaining 30 taxa. With HindIII-digested DNA, the taxon-specific pattern consisted of four bands for $S$. aureus, $S$. intermedius subsp. carnivora, $S$. hyicus, $S$. schleiferi, $S$. caseolyticus and $S$. cohnii subsp. cohnii, and five to ten bands for each of the remaining 25 taxa. Interestingly, the taxon-specific patterns for taxa which are difficult to distinguish from each other using phenotypic identification schemes, for example $S$. simulans and $S$. felis, $S$. sciuri and $S$. lentus, $S$. xylosus 


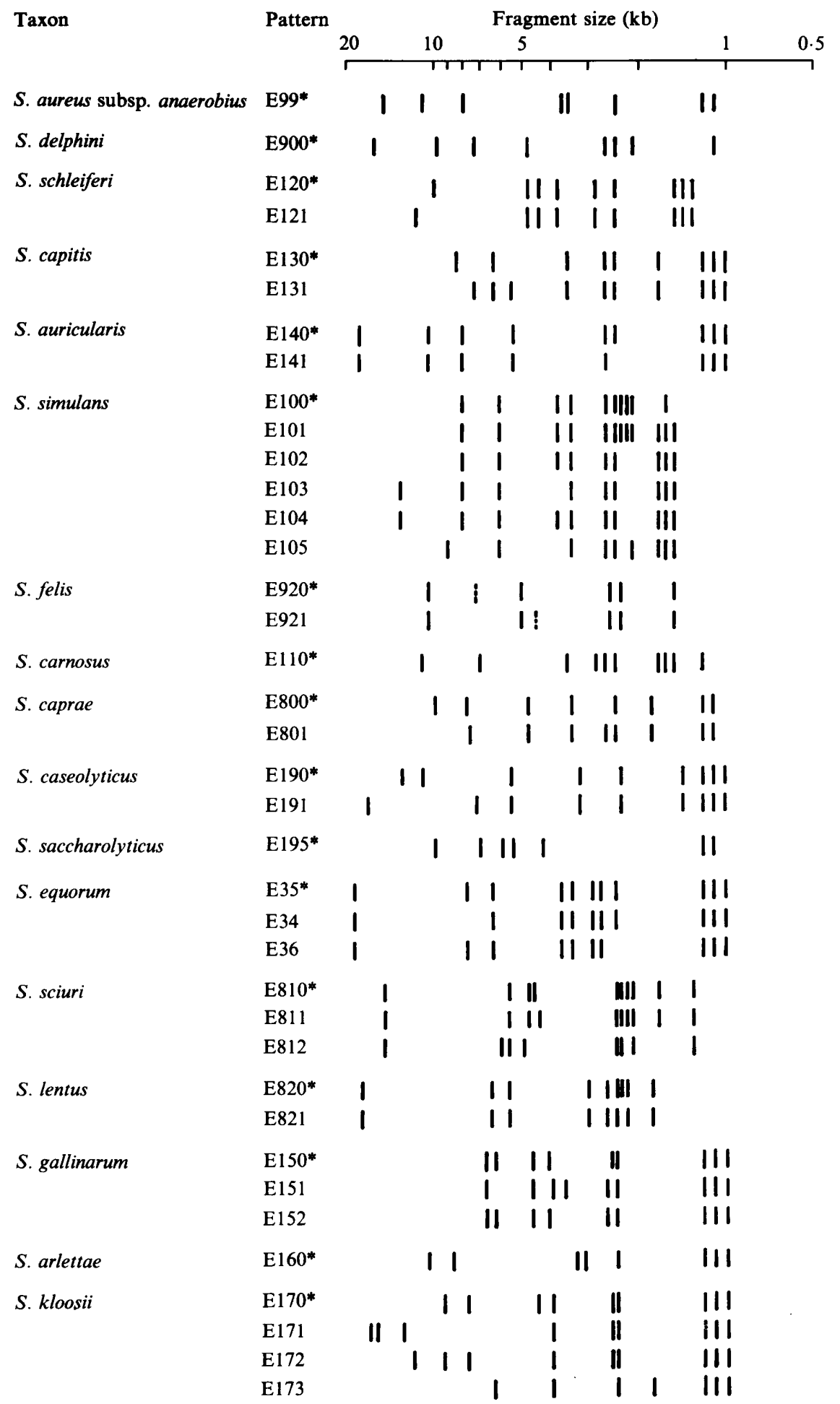

Fig. 3. Schematic representation of the 38 EcoRI-HP detected among the 75 staphylococcal isolates studied. Dashed lines indicate very weakly labelled bands. The patterns marked with an asterisk $\left(^{*}\right)$ are those corresponding to the type strain of each taxon. 


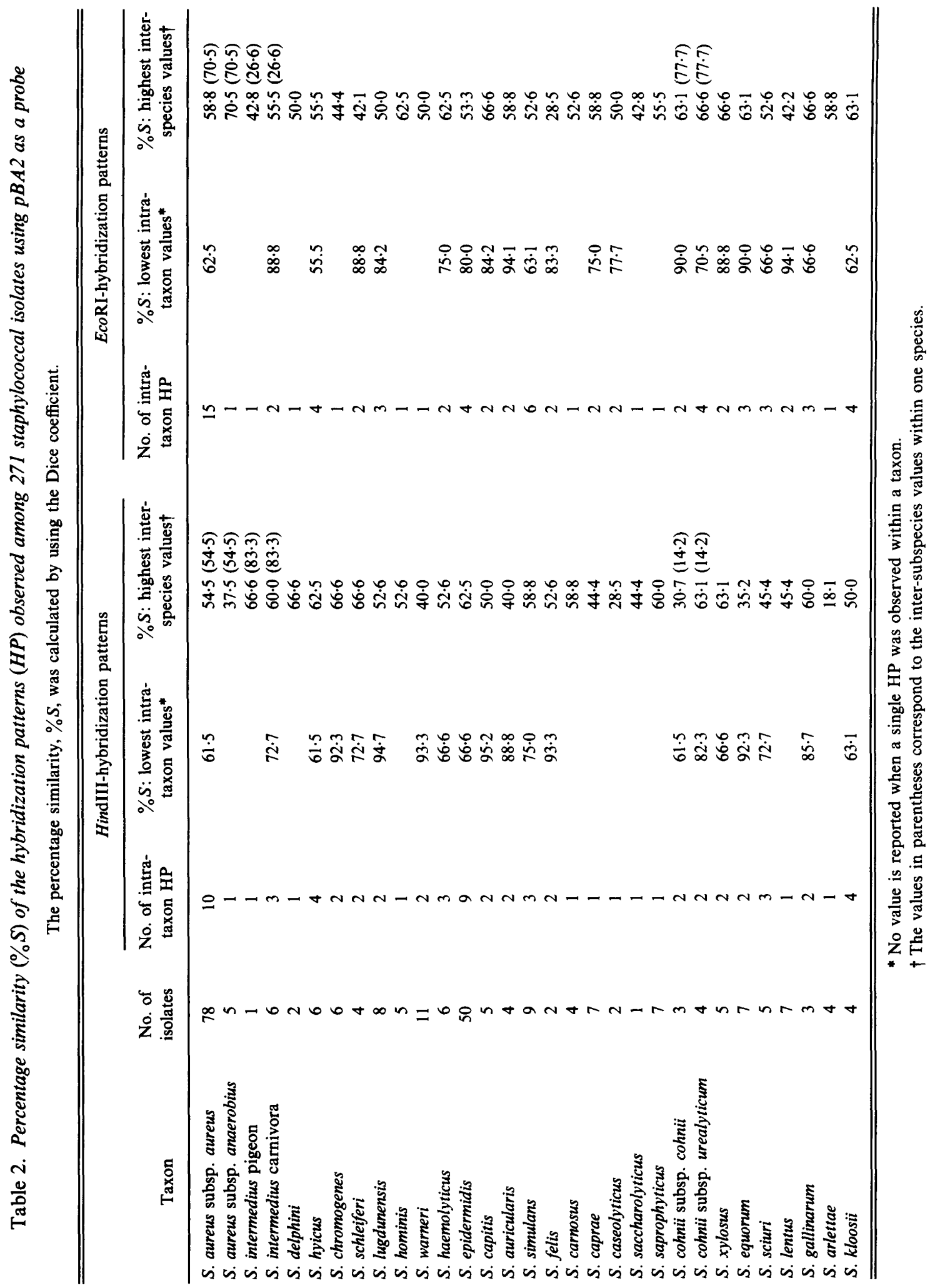




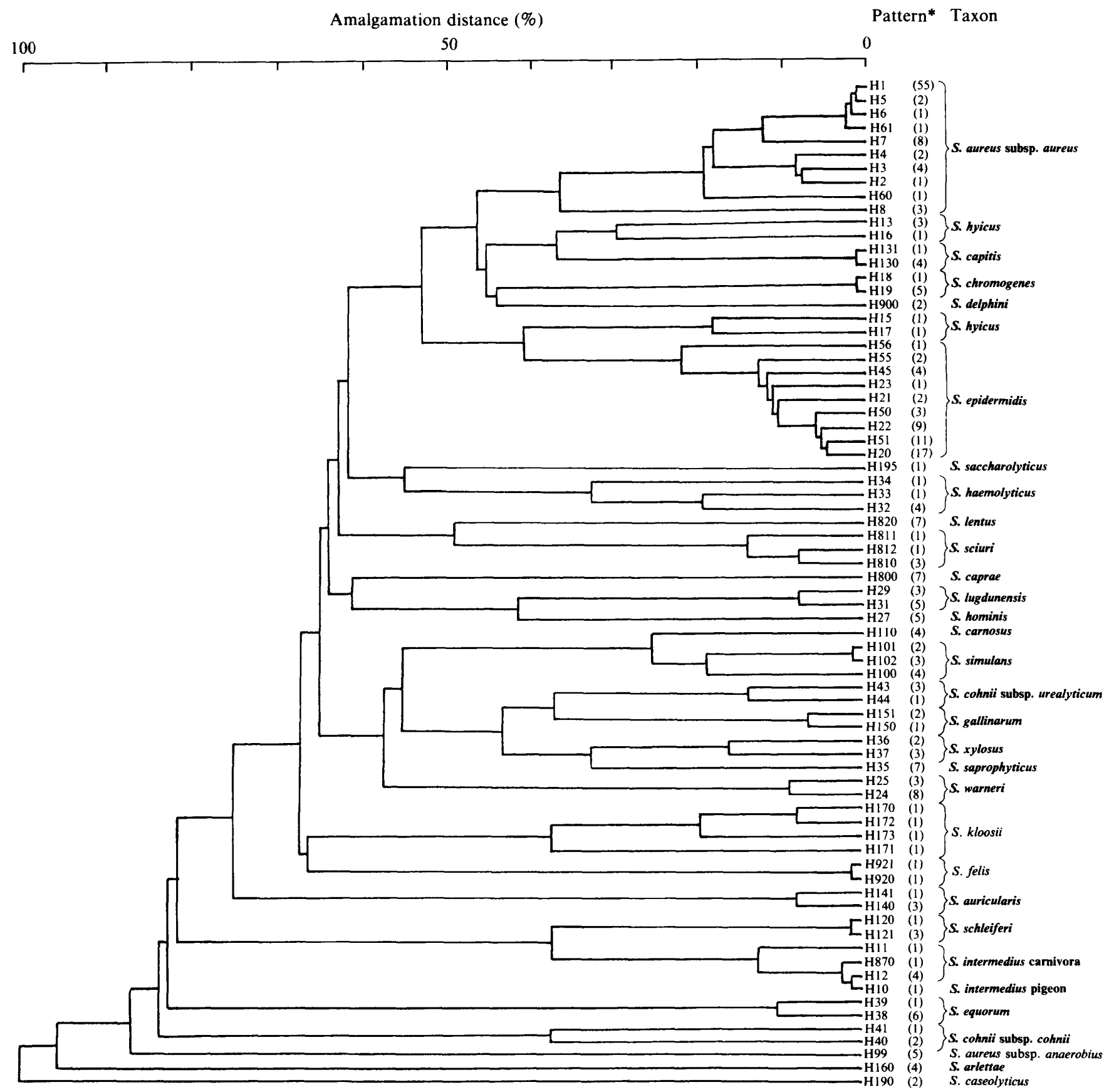

Fig. 4. Classification of the 74 HindIII-HP observed for the 271 isolates belonging to 31 staphylococcal taxa (28 species and six subspecies). Similarity between patterns was measured by using the Dice coefficient. Clustering was performed by a centroid linkage algorithm (BMDP 2M program). The horizontal axis represents the distance between patterns expressed as a percentage of the greatest amalgamation distance (0.909) found between patterns in this dendrogram. For each HP the number of strains is indicated in parentheses.

and $S$. equorum, $S$. aureus and $S$. intermedius, $S$. warneri and $S$. hominis and $S$. hyicus and $S$. chromogenes, were clearly distinct (Figs. 2 and 3; De Buyser et al., 1989).

The Dice coefficient was used to assess the similarity between the 74 HindIII HP and the 81 EcoRI HP detected among the 271 staphylococci. The taxa which may be identified by this method are those for which the lowest intra-taxon percentage of similarity $(\% S)$ is higher than the highest inter-taxa $\% S$. The values obtained are reported in Table 2. Using HindIII- and EcoRI-digested 
DNA, 29 and 26 taxa could be distinguished, respectively.

The confidence in an identification obtained using this method increases when the difference between the lowest intra-taxon $\% S$ and the highest inter-taxon $\% S$ is great. Similar discrimination was observed with HindIII and EcoRI for nine taxa, but for the remaining 22 taxa the ability to distinguish taxa varied with the enzyme used. Fourteen taxa were separated more clearly when HindIII was used to cleave the cellular DNA, whereas eight taxa were distinguished better with $E c o$ RI. The two subspecies of $S$. intermedius could only be separated from each other with EcoRI digests, whereas $S$. aureus, $S$. cohnii subsp. urealyticum, $S$. gallinarum and $S$. kloosii could only be distinguished with HindIII digests. Neither of these enzymes permitted the identification of $S$. hyicus.

The dendrogram (Fig. 4) shows the relationships between the 74 HindIII HP detected. All HindIII HP detected within the same taxon, except $S$. hyicus HP, were homogeneously clustered, showing an intra-taxon amalgamation distance varying from $0 \%$ to $38 \%$. Phenotypically close taxa such as $S$. warneri and $S$. hominis, $S$. simulans and $S$. felis, $S$. aureus and $S$. intermedius, $S$. xylosus and $S$. equorum, $S$. arlettae and $S$. gallinarum were separated by amalgamation distances of at least $65 \%$. The two subspecies delineated within $S$. cohnii and $S$. aureus were also separated by high distances $(\geqslant 83 \%)$.

\section{Discussion}

The method based on rRNA gene restriction fragment lengh polymorphisms has been proposed for discriminating between species of Staphylococcus (De Buyser et al., 1989; Thomson-Carter et al., 1989; El Solh et al., 1990; Bialkowska-Hobrzanska et al., 1990 ; Pennington et al., 1991). In this study, we report the comparative analysis of the HindIII- and EcoRI-HP of cellular DNA from 271 isolates belonging to 31 staphylococcal taxa (28 species, six subspecies), using a cloned $2.3 \mathrm{~kb}$ DNA fragment encoding 16S rRNA from Bacillus subtilis as a probe (Iglesias et al. 1983). Thomson-Carter et al. (1989) studied 22 isolates belonging to seven species, using HindIII and EcoRI to cleave cellular DNA and $16 \mathrm{~S}+23 \mathrm{~S}$ rRNA from $E$.coli as a probe. BialkowskaHobrzanska et al. (1990 b), using the same probe, studied 78 strains belonging to 15 species after cleavage of cellular DNA with ClaI. In each of these studies, a taxonspecific core of common bands was detected in the HP. These cores varied from one study to another because of the use of distinct probes and restriction enzymes. In the present study, all of the currently described staphylococcal species were analysed using the same probe and endonucleases, thus creating a database for the accurate identification of any staphylococcal isolate.

To evaluate the discriminating ability of the method, it was necessary to calculate the lowest intra-taxon- and the highest inter-taxon- $\% S$ between the HP for each taxon and for each of the two enzymes tested. The use of HindIII yielded a better discrimination of most of the staphylococcal taxa. However, the two subspecies of $S$. intermedius could only be separated using EcoRI. Moreover, $S$. hyicus could not be easily distinguished either with HindIII or with EcoRI. Grimont \& Grimont (1986) have shown that divergence in DNA-DNA hybridization within the species Salmonella or Serratia resulted in significant intra-taxon diversity of patterns. DNA-DNA hybridization (Devriese et al., 1978; Kloos, 1980), numerical taxonomy (Hoover et al., 1983) as well as miniaturized and conventional identification methods (Lämmler, 1991) showed a divergence between $S$. hyicus isolates obtained from phylogenetically distant hosts. Heterogeneity observed within $S$. hyicus HP may therefore be attributed to the diversity of hosts (pig, horse, poultry, cow) of the isolates we examined in this study. Nevertheless, $S$. hyicus HP could clearly be distinguished from the HP detected within the phenotypically close taxa $S$. aureus, $S$. intermedius and $S$. chromogenes.

The method proposed in this study is regularly used in our Reference Centre when the use of simple phenotypic identification schemes fails to identify a staphylococcal isolate to any of the described species. The HP obtained with distinct DNA preparations and independent agarose gel electrophoresis are reproducible. For each unknown isolate, the sizes of the EcoRI and HindIII hybridizing bands are compared with those obtained previously (De Buyser et al., 1989; El Solh et al., 1990) and in the present study. Since this method appears to be limited by the lack of precision with which the sizes of the hybridizing bands are evaluated, the sizes are measured by comparison not only with those of a Raoul I ladder but also with those of the HP obtained from staphylococcal type strains belonging to the most phenotypically close taxa, run side-by-side on the same gel. Non-radioactive labelling of the probes provides better resolution between the hybridization bands (Altwegg \& Mayer, 1989) and is now being tested to improve the accuracy of size measurements.

In conclusion, the method presented in this study constitutes a powerful tool for the identification of staphylococcal isolates. Taxa which are difficult to separate using phenotypic tests are clearly distinguished. This method cannot replace quantitative DNA-DNA hybridization studies for estimating genomic relationships between staphylococci. However, it does permit the rapid screening of new taxa. 
We thank Keith Dyke for criticism of the manuscript, Fredj Teicaia, Michel Veron and Christine Coustère for their help in statistical analysis of data and Odette Rouelland for secretarial assistance.

\section{References}

AltwegG, M. \& MAYeR, L. W. (1989). Bacterial molecular epidemiology based on a non-radioactive probe complementary to ribosomal RNA. Research in Microbiology 140, 325-333.

BaIRD-PARKer, A. C. (1974). Genus II. Staphylococcus. In Bergey's Manual of Determinative Bacteriology, 8th edn. Edited by R. E. Buchanan \& N. E. Gibbons. Baltimore: Williams \& Wilkins.

BANNERMAN, T. L. \& KloOs, W. E. (1991). Staphylococcus capitis subsp. ureolyticus subsp.nov. from human skin. International Journal of Systematic Bacteriology 41, 144-147.

BialKowSKa-HobrZaNSKa, H., Jaskot, D. \& HAMmerberg, $O$. $(1990 a)$. A method for DNA restriction endonuclease fingerprinting of coagulase-negative staphylococci. Journal of Microbiological Methods 12, 41-49.

BIALKOWSKa-HOBRZANSKa, H., HARRY, V., JASKOT, D. \& HAMMERBERG, O. (1990 b). Typing of coagulase-negative staphylococci by Southern hybridization of chromosomal DNA fingerprints using a ribosomal RNA probe. European Journal of Clinical Microbiology and Infectious Diseases 9, 588-594.

Bolivar, F., Rodriguez, R. L., Greene, P. J., Betlach, M. C., HeYNeKer, H. L., Boyer, H. W., Crosa, J. H. \& Falkow, S. (1977). Construction and characterization of new cloning vehicles. II. A multipurpose cloning system. Gene 2, 95-113.

Brun, Y., Bes, M., Boeufgras, J. M., Monget, D., Fleurette, J., Auckenthaler, R., Devriese, L. A., Kocur, M., Marples, R. R., Piemont, Y., Poutrel, B. \& Schumacher-Perdreau, F. (1990). International collaborative evaluation of the ATB 32 Staph gallery for identification of the Staphylococcus species. Zentralblatt für Bakteriologie 273, 319-326.

Clink, J. \& Pennington, T. H. (1987). Staphylococcal whole-cell polypeptide analysis: evaluation as a taxonomic and typing tool. Journal of Medical Microbiology 23, 41-44.

De BuYser, M. L., Morvan, A., Grimont, F. \& El Solh, N. (1989). Characterization of Staphylococcus species by ribosomal RNA gene restriction patterns. Journal of General Microbiology 135, 989999.

De La Fuente, R., Suarez, G. \& Schleifer, K. H. (1985). Staphylococcus aureus subsp. anaerobius subsp. nov., the causal agent of abscess disease of sheep. International Journal of Systematic Bacteriology 35, 99-102.

Devriese, L. A., Hajex, V., Oeding, P., Meyer, S. A. \& Schleifer, K. H. (1978). Staphylococcus hyicus (Sompolinsky 1953) comb. nov. and Staphylococcus hyicus subsp. chomogenes subsp. nov. International Journal of Systematic Bacteriology 28, 482-490.

Devriese, L. A., Schleifer, K. H. \& Adegoke, G. O. (1985). Identification of coagulase-negative staphylococci from farm animals. Journal of Applied Bacteriology 58, 45-55.

DiCE, L. R. (1945). Measure of the amount of ecological association between species. Ecology 26, 297-302.

El Solh, N., De Buyser, M. L., Morvan, A., Grimont, F., SalesseWalcher, S., Aubert, S., Monzon-Moreno, C., Chesneau, O. \& Allignet, J. (1990). Use of Bacillus subtilis 16S rRNA genes as a probe to identify species, subspecies and types in the genus Staphylococcus. In Molecular Biology of the Staphylococci, pp. 585593. Edited by R. P. Novick. New York: VCH Publishers.

Endl, J., Seidl, H. P., Fiedler, F. \& Schileifer, K. H. (1983). Chemical composition and structure of cell wall teichoic acids of staphylococci. Archives of Microbiology 135, 215-223.

Fischer, S., Tsugita, A., Kreutz, B. \& Schleifer, K. H. (1983) Immunochemical and protein-chemical studies of class I fructose 1 , 6-diphosphate aldolases from staphylococci. International Journal of Systematic Bacteriology 33, 443-450.

Fontana, R., Varaldo, P. E., Canepari, P. \& Satta, G. (1981). Analysis of the penicillin-binding proteins in the membranes of staphylococci of different lyogroups (or species). Zentralblatt für Bakteriologie, Parasitenkunde, Infektionskrankheiten und Hygiene (Abt. I, suppl.) 10, 67-70.

Freney, J., Brun, Y., Bes, M., Meugnier, H., Grimont, F., Grimont, P. A. D., Nervi, C. \& Fleurette, J. (1988). Staphylococcus lugdunensis sp.nov. and Staphylococcus schleiferi sp.nov., two species from human clinical specimens. International Journal of Systematic Bacteriology 38, 168-172.

Goodfellow, M., Alderson, G., Nahaie, M. R., Peters, G., Schumacher-Perdreau, F., Pulverer, G., Heczko, P. B. \& MORDARSKI, M. (1983). Numerical taxonomy of staphylococci. Zentralblatt für Bakteriologie, Mikrobiologie und Hygiene (Abt. I, originale A) 256, 7-24.

GöTZ, F. \& SCHLEIFER, K. H. (1976). Comparative biochemistry of lactate dehydrogenases from staphylococci. In Staphylococci and Staphylococcal Diseases, pp. 245-252. Edited by J. Jeljaszewicz. Stuttgart: Gustav Fisher.

Grimont, F. \& Grimont, P. A. D. (1986). Ribosomal ribonucleic acid gene restriction patterns as potential taxonomic tools. Annales de l'Institut Pasteur/Microbiologie 137B, 165-175.

GunN, B. A., Keiser, J. F. \& Colwell, R. R. (1983). Numerical taxonomy of staphylococci isolated from clinical sources. International Journal of Systematic Bacteriology 33, 738-750.

Hébert, G. A., Crowder, C. G., Hancock, G. A., Jarvis, W. R. \& THORNSBERRY, C. (1988). Characteristics of coagulase-negative staphylococci that help differentiate these species and other members of the family Micrococcaceae. Journal of Clinical Microbiology 26, 1939-1949.

Helm, D., Labischinsti, H., Schallehn, G. \& NaumanN, D. (1991). Classification and identification of bacteria by Fourier-transform infrared spectroscopy. Journal of General Microbiology 137, 6979.

Hoover, D. G., Tatini, S. R. \& Maltais, J. B. (1983). Characterization of staphylococci. Applied and Environmental Microbiology 46, 649-660.

Igimi, S., Kawamura, S., Takahashi, E. \& Mitsuoka, T. (1989). Staphylococcus felis, a new species from clinical specimens from cats. International Journal of Systematic Bacteriology 39, 373-377.

Igimi, S., Takahashi, E. \& Mitsuoka, T. (1990). Staphylococcus schleiferi subsp. coagulans subsp. nov., isolated from the external auditory meatus of dogs with external ear otitis. International Journal of Systematic Bacteriology 40, 409-411.

Iglesias, A., Ceglowski, P. \& Trautner, T. A. (1983). Plasmid transformation in Bacillus subtilis. Effects of the insertion of Bacillus subtilis rRNA genes into plasmids. Molecular and General Genetics 192, 149-155.

KLOOs, W. E. (1980). Natural populations of the genus Staphylococcus. Annual Review of Microbiology 34, 559-592.

KLOOS, W. E. \& GEORGE, C. G. (1991). Identification of Staphylococcus species and subspecies with the MicroScan Pos ID and Rapid Pos ID Panel Systems. Journal of Clinical Microbiology 29, 738-744.

KLOOS, W. E. \& SCHLEIFER, K. H. (1986). Genus IV. Staphylococcus. In Bergey's Manual of Systematic Bacteriology, vol. 2, pp. 1013-1035. Edited by P. H. A. Sneath. N. S. Mair, M. E. Sharpe \& J. G. Holt. Baltimore: Williams \& Wilkins.

KLOOS, W. E. \& WOLFSHOHL, J. F. (1991). Staphylococcus cohnii subspecies: Staphylococcus cohnii subsp. cohnii subsp. nov. and Staphylococcus cohnii subsp. urealyticum subsp. nov. International Journal of Systematic Bacteriology 41, 284-289.

LÄMMLER, C. (1991). Characterization of Staphylococcus hyicus with the ATB 32 Staph System and with conventional tests. Journal of Clinical Microbiology 29, 1221-1224.

O'Donnell, A. G., Nahaie, M. R., Goodfellow, M., Minnikin, D. E. \& HAJEK, V. (1985). Numerical analysis of fatty acid profiles in the identification of staphylococci. Journal of General Microbiology 131, 2023-2033.

Pennington, T. H., Harker, C. \& Thomson-Carter, F. (1991). Identification of coagulase-negative staphylococci by using sodium dodecyl sulfate-polyacrylamide gel electrophoresis and rRNA restriction patterns. Journal of Clinical Microbiology 29, 390-392.

Pierre, J., GutmanN, L., Bornet, M., Bergogne-Berezin, E. \& Williamson, R. (1990). Identification of coagulase negative- 
staphylococci by electrophoretic profile of total proteins and analysis of penicillin-binding proteins. Journal of Clinical Microbiology 28, 443-446.

Pillet, J. \& OrTa, B. (1981). Species and serotypes in coagulasenegative staphylococci. In Staphylococci and Staphylococcal infections, Zentralblatt für Bakteriologie, Mikrobiologie und Hygiene (Abt. I, Suppl.) 10, 147-152.

SCHLEIFER, K. H., MEYER, S. A. \& RUPPRECHT, M. (1979). Relatedness among coagulase-negative staphylococci: deoxyribonucleic acid reassociation and comparative immunological studies. Archives of Microbiology 122, 93-101.

SChumaCher-Perdreau, F., Rotering, H. \& Pulverer, G. (1983). Cell wall analysis and taxonomy of staphylococci. Zentralblatt für Bakteriologie, Mikrobiologie und Hygiene (Abt. I, originale A) 256, 2536.

Thomson-Carter, F. M., Carter, P. E. \& Pennington, T. H. (1989). Differentiation of staphylococcal species and strains by ribosomal
RNA gene restriction patterns. Journal of General Microbiology 135 , 2093-2097.

VARALDO, P. E. \& SATTA, G. (1978). Grouping of staphylococci on the basis of their bacteriolytic-activity patterns: a new approach to the taxonomy of the Micrococcaceae. International Journal of Systematic Bacteriology 28, 148-153.

Varaldo, P. E., Kilpper-Bälz, R., Biavasco, F., Satta, G. \& SCHLEIFER, K. H. (1988). Staphylococcus delphini sp. nov., a coagulase-positive species isolated from dolphins. International Journal of Systematic Bacteriology 38, 436-439.

ZIMMERMAN, R. J. (1976). Comparative zone electrophoresis of catalase of Staphylococcus species isolated from mammalian skin. Canadian Journal of Microbiology 22, 1691-1698.

Zimmerman, R. J. \& Kloos, W. E. (1976). Comparative zone electrophoresis of esterases from Staphylococcus species isolated from mammalian skin. Canadian Journal of Microbiology 22, 771779. 